\title{
THE IMPACT ANALYSIS OF ASEAN-JAPAN COMPREHENSIVE ECONOMIC PARTNERSHIP (AJCEP) FOR TRADE FLOW AND ECONOMIC GROWTH'S CONVERGENCE
}

\author{
Tri Arifin Darsono ${ }^{1}$, Dedi Budiman Hakim², Wiwiek Rindayati ${ }^{2}$ \\ ${ }^{1}$ Mahasiswa Magister Program Studi Ilmu Ekonomi, FEM IPB \\ ${ }^{2}$ Staf Pengajar FEM IPB
}

Artikel diterima Maret 2015

Artikel disetujui untuk dipublikasikan Juli 2015

\begin{abstract}
Free Trade Area (FTA) between ASEAN and Japan, which is called ASEAN-Japan Comprehensive Economic Partnership (AJCEP), has been established since 2002 as goods and services flow gateway. AJCEP plays an important role to bring the development, economic security, and economic power. It can also boost the economic growth among member of ASEAN-Japan. The objectives of this research were to analyze the factors that can influence the ASEAN-Japan countries import with non-member, to analyze the occurrence of trade creation and trade diversion in trading sector among ASEAN-Japan countries with non-member, and to analyze the occurrence of economic growth's convergence in ASEAN-Japan Comprehensive Economic Partnership (AJCEP) not only among ASEAN-Japan countries, but also with non-member trading partners. The Gravity Model was used to analyze import factors and observing the occurrence of trade creation or trade diversion. The GMM model was used to observe the convergence of economic growth. The research are used Panel data methods with periods 2000 until 2013 in 13 countries.

The research found that the coefficient values in trade creation and trade diversion dummy were 0.92 and 31.41. The positive value in trade creation and trade diversion indicated the occurrence of trade creation in the import flow among ASEAN-Japan countries and non-member trading partners, as well as finding the convergence of economic growth among ASEAN-Japan countries. The convergence level was of 0.0153417 can be interpreted that the velocity to reach steady state condition was 2.00 percent per year with the assumption of ceteris paribus. The duration to reach convergence condition or half life of convergence was about 34 years. The research found the trade creation from AJCEP agreement and the occurrence of economic growth's convergence. Based on the result, Indonesian government would likely to make relationships among countries member and non-member to invest in real sector that will boost economic growth in Indonesia.
\end{abstract}

Keywords: ASEAN-Japan Comprehensive Economic Partnership, Growth's convergence, gravity model, GMM model, trade creation, trade diversion.

\section{PENDAHULUAN}

Salah-satu kesempatan penting dari perluasan jaringan ekonomi antar kawasan yang terus meningkat adalah kerjasama FTA ASEAN-Jepang dikenal dengan ASEAN-Japan Comprehensive Economic Partnership (AJCEP) yang berlangsung 
pada tahun 2002. Bagi hampir seluruh negara di kawasan ASEAN, Jepang merupakan satu satu mitra terbesar dalam ekonomi khususnya di bidang investasi. AJCEP sebagai pintu masuk pada antara Indonesia dan negara-negara ASEAN lainnya dengan Jepang adalah peluang penting bagi pembangunan ketahanan ekonomi nasional berkaitan dengan kekuatan ekonomi yang dimiliki Jepang yang dapat memacu petumbuhan ekonomi Indonesia melalui hubungan bilateral yang lebih erat sehingga dapat meningkatkan ketahanan ekonomi nasional (ASEAN org).

Kerja sama ini kemudian diperluas dengan masuknnya negara yang jauh lebih maju seperti China, Jepang, Korea Selatan, Australia, India, dan Amerika. Semakin meluasnya kerja sama yang dilakukan, diharapkan dapat memberikan efek positif terhadap perekonomian masing-masing negara anggotanya. Terdapat harapan bagi terciptanya iklim pertumbuhan ekonomi yang sehat dapat segera terpenuhi, sehingga dapat dihasilkan suatu peningkatan perekonomian oleh masing-masing negara anggota. Namun apakah masuknya negara-negara maju ini dapat secara efektif membantu majunya negara berkembang di kawasan ASEAN, karena kerja sama tersebut juga sekaligus meningkatkan persaingan di antar negara anggota sendiri. Terdapat kemungkinan peningkatan perekonomian negara-negara anggota terutama negara berkembang dengan kemudahan mobilitas kapital dan perdagangan antar negara, namun di sisi lain juga kemungkinan dapat meningkatkan ketimpangan antar negara karena hanya negara maju saja yang dapat memanfaatkan dengan baik (Mankiw 2007).

Berdasarkan data yang diperoleh dari trade map tahun 2015, komoditi impor utama Indonesia dari Jepang dapat dilihat pada Gambar 3. Produk impor yang masuk ke Indonesia dari jepang adalah mesin, reaktor nuklir, boiler, kendaraan bermotor, besi baja, bahan kimia, peralatan elektronik, plastik dan barang plastik, karet dan barang dari karet, kapal dan other floating structures, dan manmade staple fibers. Nilai impor tertinggi Indonesia dari Jepang pada tahun 2007 ke tahun 2008 rata-rata produk impor Jepang meningkat secara signifikan rata-rata peningkatannya mencapai 50 persen untuk setiap produknya. Untuk produk mesin, reaktor nuklir, dan boiler pada tahun 2007 impornya sebesar 2232747 USD, dan pada tahun 2008 meningkat menjadi 4240 599 USD. Besar impor untuk produk kendaraan bermotor pada tahun 2007 sebesar 950740 USD, pda tahun 2008 impor kendaraan bermotor sebesar 2763 142 USD peningkatan yang sangat signifikan sejak diberlakukannya IJEPA. Sementara untuk produk-produk impor lainnya seperti produk elektronik besar impor pada tahun 2007 sebesar 488616 USD, sedangkan pada tahun 2008 terjadi peningkatan yang signifikan menjadi 1984 110 USD.

Krisis ekonomi dunia akhir tahun 2008 sangat mempengaruhi impor Indonesia dari Jepang sebagaimana diperlihatkan pada Gambar 3. Penurunan impor Indonesia dari Jepang secara drastis terjadi sejak periode November 2008 hingga September 2010 akibat krisis, dan baru kembali normal sejak Oktober 2010. Produk impor jepang seperti mesin, reaktor nuklir dan boiler pada tahun 2008 sebesar 4240599 USD turun menjadi 2731975 USD pada tahun 2009, begitupun untuk produk-produk lain semua mengalami penurunan pada tahun ini, namun pada tahun 2010 mengalami peningkatan lagi yang menandakan sudah stabilnya perekonomian dunia. 


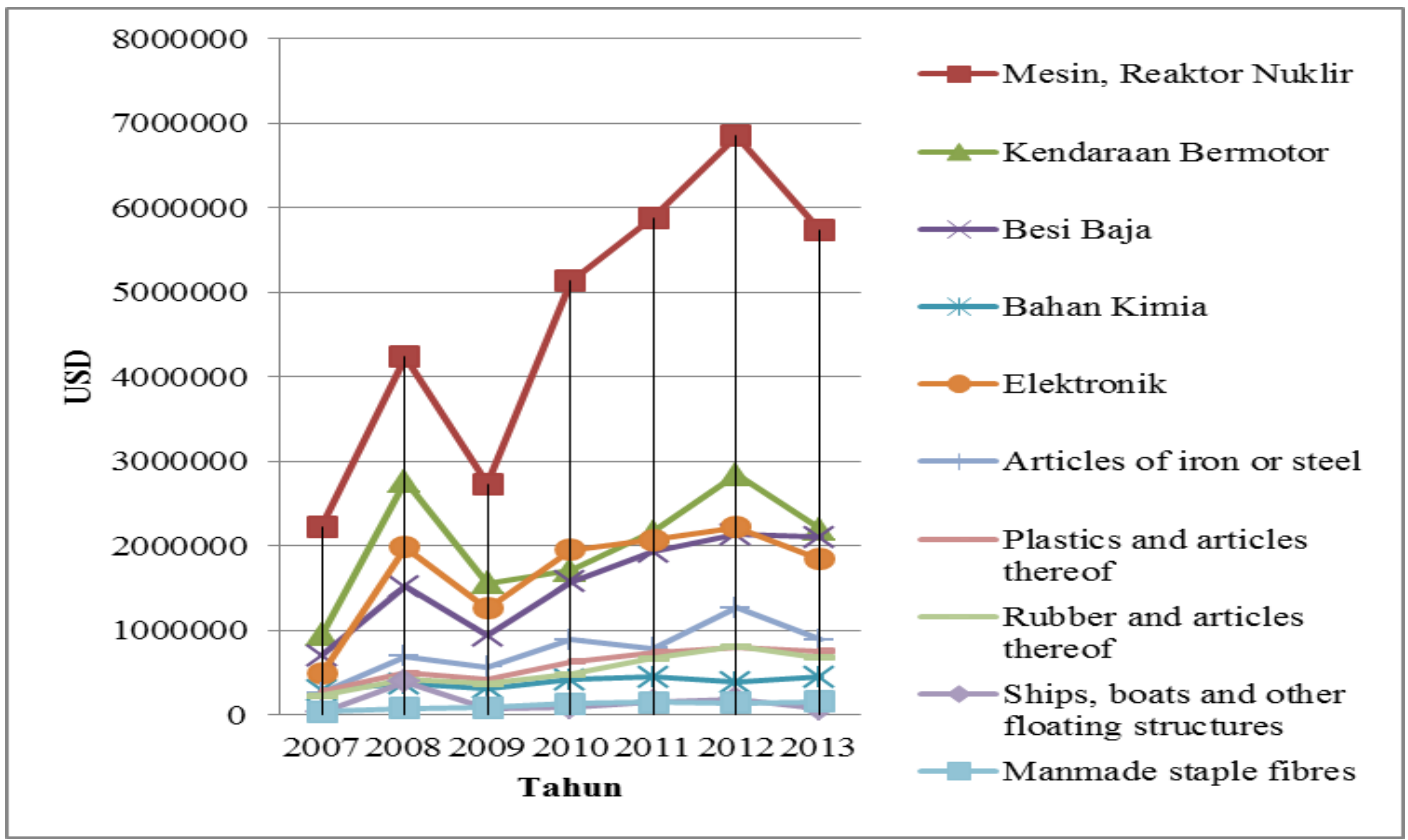

Sumber: Trade Map (2015)

Gambar 1 Produk impor Indonesia dari Jepang tahun 2007-2013

Berdasarkan data yang diperoleh dari trade map tahun 2015, komoditi impor utama Indonesia dari negara-negara ASEAN dapat dilihat pada Gambar 4. Produk impor yang masuk ke Indonesia dari negara-negara ASEAN adalah mesin, reaktor nuklir, boiler, barang-barang elektronik, barang-barang dari plastik, kendaraan bermotor kecuali kereta api, bahan kimia organik, besi baja, gula, optical, photo, dan bahan-bahan medis. Untuk produk mesin, reaktor nuklir, dan boiler pada tahun 2007 impornya sebesar 1 869218 USD, dan pada tahun 2008 meningkat menjadi 4405224 USD. Besar impor untuk produk produk elektronik besar impor pada tahun 2007 sebesar 613 651 USD, pada tahun 2008 terjadi peningkatan yang signifikan yang mana nilai impornya menjadi 3875230 USD. Sementara untuk produk-produk impor lainnya seperti produk kendaraan bermotor pada tahun 2007 nilai impor sebesar 1114 968 USD, pada tahun 2008 impor kendaraan bermotor meningkat sebesar 2 478188 USD. Bisa dilihat pada Gambar 4. Impor Indonesia dari Jepang sebagai berikut.

Krisis ekonomi dunia akhir tahun 2008 sangat mempengaruhi impor Indonesia dari negara ASEAN sebagaimana diperlihatkan pada Gambar 4. Penurunan impor Indonesia dari ASEAN tidak terlalu besar jika dibandingkan dengan penurunan impor Indonesia dari Jepang, dan baru kembali normal sejak Oktober 2010. Produk impor jepang seperti mesin, reaktor nuklir dan boiler pada tahun 2008 sebesar 4405224 USD turun menjadi 3597404 USD pada tahun 2009 dan pada tahun 2010 terjadi peningkatan kembali sebesar 4163924 USD, begitupun untuk produk-produk lain semua mengalami penurunan pada tahun ini, namun pada tahun 2010 mengalami peningkatan lagi yang menandakan sudah stabilnya perekonomian dunia. 


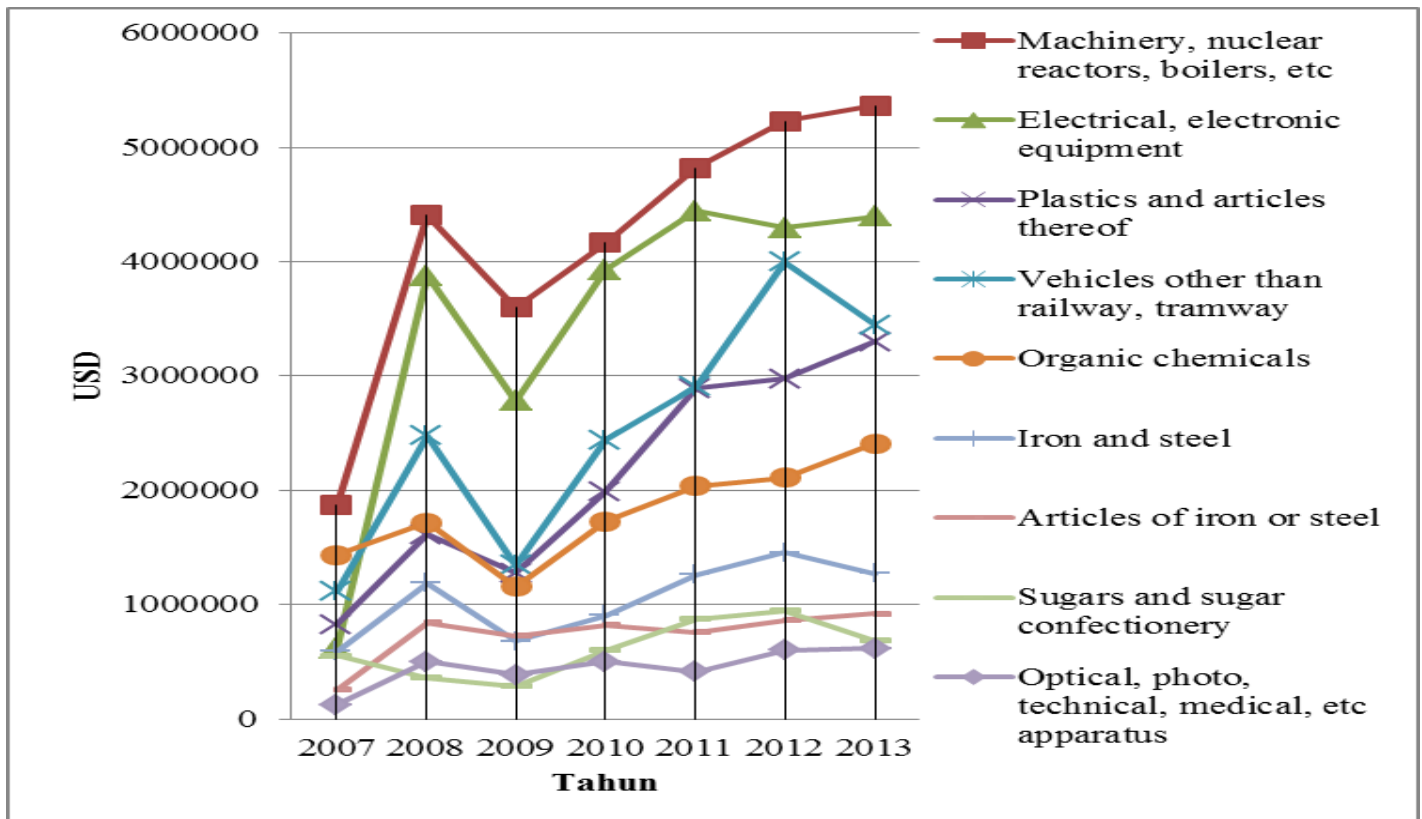

Sumber: Trade Map (2015)

Gambar 2 Impor Indonesia dari negara-negara ASEAN tahun 2007-2013

Dampak ekonomi dari FTA dapat dibagi dalam dampak statis dan dampak dinamis. Dalam dampak statis tercakup dampak penurunan tarif standar atas efisiensi alokasi sumber daya, dan dampak dinamis, di mana produktivitas yang lebih tinggi dan akumulasi modal berdampak pada pertumbuhan ekonomi (Kemendag 2011).

Dampak statis adalah penciptaan perdagangan dan mengurangi pembelokan (diversion). Mengurangi atau penghapusan hambatan perdagangan antara pihak-pihak yang mengadakan persetujuan FTA yang akan merubah harga barang-barang dan jasa yang diperdagangkan, pada gilirannya berpengaruh pada volume perdagangan dan kesejahteraan ekonomi kedua negara. Penghapusan hambatan perdagangan berarti terjadinya perluasan perdagangan yang dilakukan antara pihak bersangkutan, dengan menggerakkan konsumen dalam negara yang mengimpor barang dan jasa dengan harga lebih murah, dan di pihak produsen negara pengekspor memperoleh laba sebagai hasil ekspor yang lebih besar. Secara teoritis kemakmuran kedua negara dengan adanya FTA akan semakin membaik (improving the economic welfare).

Indonesia selaku anggota yang melakukan kesepakatan perdagangan dengan ASEAN dan Jepang dengan mengurangi dan pengahapusan tarif, oleh karena itu bahwa peniadaan hambatan sebagai akibat FTA tidak serta merta membawa dampak untuk Indonesia. Dampak FTA juga pada pertumbuhan ekonomi kedua belah pihak melalui tahapan peningkatan produktivitas yang mencakup perluasan pasar, peningkatan daya saing, alih teknologi disertai inovasi teknologi (Kemendag 2011).

Trade creation (penciptaan perdagangan) terjadi ketika beberapa produk yang produksi dalam negeri digantikan oleh produk impor dengan biaya produksi yang relatif lebih murah yang mana produknya berasal dari negara anggota, maka dengan adanya kegiatan ini maka akan meningkat kesejahteraan negara-negara tersebut (Salvatore 1996). Dalam trade diversion, hal ini terjadi ketika barang impor dengan biaya yang lebih rendah dari luar serikat atau non anggota digantikan oleh barang impor dengan biaya yang lebih tinggi dari negara 
anggota, dengan sendirinya hal ini akan mengurangi kesejahteraan (Salvatore 1996). Pengalihan ini akan menghasilkan penambahan biaya dan dapat mengurangi pendapatan suatu negara.

Untuk mengantisipasi banyaknya produk impor yang masuk ke pasar Indonesia, pemerintah telah membuat suatu kebijakan yang berkenaan dengan tarif bea masuk dalam IJEPA yang tertuang dalam peraturan menteri keuangan (PMK) No. 95/PMK.011/2008 tentang penetapan tarif bea masuk dalam rangka persetujuan antara Indonesia dengan Jepang mengenai suatu kemitraan ekonomi. Peraturan Menteri Keuangan telah disesuaikan dengan kesepakatan yang diperoleh saat IJEPA terbentuk (Kemenkeu 2011).

Oleh karena itu berdasarkan uraian diatas tujuan dari penelitian ini adalah Menganalisis terjadinya trade creation dan trade divertion di sektor perdagangan antara Indonesia dan negara ASEAN, Jepang. Menganalisis faktor-faktor yang mempengaruhi impor negara ASEAN-Jepang dan non anggota dari kesepakatan ASEAN-Japan Comprehensive Economic Partnership (AJCEP), menganalisis terjadinya trade creation dan trade diversion dari perjanjian ASEAN-Japan Comprehensive Economic Partnership (AJCEP) antara negara ASEAN-Jepang dengan negara non anggota, dan menganalisis terjadinya konvergensi pertumbuhan ekonomi dari kesepakatan ASEAN-Japan Comprehensive Economic Partnership (AJCEP) negara ASEAN-Jepang dengan non anggota.

\section{METODE PENELITIAN Jenis dan Sumber Data}

Jenis data dan sumber data yang digunakan dalam penelitian ini adalah data time series dan data cross section dan data sekunder. Data time series yang digunakan adalah data tahunan dari tahun 2000 sampai tahun 2013 dan cross section yang terdiri dari delapan negara anggota ASEAN yaitu, Indonesia, Malaysia, Singapura, Filipina, Thailand, Laos, Brunai Darusalam, Kamboja, Jepang dan empat negara pengimpor utama Indonesia yaitu Cina, Korea Selatan, Amerika Serikat, Australia.

Data yang digunakan dalam penelitian adalah nilai impor, GDP, populasi, dummy FTA, dan jarak negara, GDP perkapita, foreign direct investment, household final consumption expenditure, total perdagangan., ini merupakan data sekunder yang berasal dari berbagai sumber, yaitu ASEANStat, World Bank (World Development Indicators WDI 2015), International Monetary Fund (International Financial Statistics 2012), Trademap, CEPII, Kementerian Perdagangan dan sumber-sumber lainnya.

\section{Metode Analisis}

Metode analisis yang digunakan dalam penelitian adalah menggunakan analisis deskriptif dan analisis data panel dengan model panel statis yaitu menggunakan model gravity dan model panel dinamis dengan menngunakan model generalized method of movements (GMM). Analisis ekonometrika dengan regresi data panal gravity digunakan untuk melihat keterkaitan antara arus perdagangan dan perekonomian suatu negara dengan menganalisis apakah terjadi tarde creation atau trade divertion dan melihat faktor-faktor yang mempengaruhi impor Indonesia, negara-negara ASEAN, dan Jepang, serta mitra dagang Indonesia, dan juga melihat konvergensi pertumbuhan ekonomi di kawasan ASEAN Jepang dan mitra dagang Indonesia.

\section{Gravity Model}

Model gravitasi digunakan untuk menganalisis pola aliran perdagangan bilateral antar negara-negara dalam suatu 
wilayah tertentu sebagai sebuah fungsi dari masa ekonomi masing-masing negara, jarak antar negara, dan faktor lainnya. Gravity model saat ini lazim digunakan sebagai sebuah metode yang mampu mengevaluasi potensi perdagangan suatu produk atau jasa antar negara serta mampu melihat besarnya suatu wilayah. Latar belakang terbentuknya model gravitasi ini adalah bahwa negara yang lebih kaya akan lebih banyak melakukan perdagangan ke luar negeri bila dibandingkan dengan negara-negara yang lebih miskin dimana jarak yang semakin jauh dianggap bukan sebagai hambatan. Persamaan dasar dari model gravity berdasarkan (Starck CS 2012), yaitu:

$$
T i j=A \times Y i \times Y j / D i j
$$

Keterangan:

$\mathrm{T}_{\mathrm{ij}}=$ Nilai perdagangan antara negara $\mathrm{i}$ dan negara $\mathrm{j}$
$\mathrm{Y}_{\mathrm{i}}=$ GDP negara $\mathrm{i}$

$\mathrm{Y}_{\mathrm{j}}=$ GDP negara $\mathrm{j}$

$\mathrm{A}=$ Konstanta

$\mathrm{D}_{\mathrm{ij}}=$ Jarak di antara kedua negara

Latar belakang penamaan gravity model ini merupakan analogi dari teori garvitasi Newton, yang mana gaya tarik gavitasi diantara dua objek bersifat proporsional terhadap massa dan jarak. Jadi ketika dibawakan ke dalam perdagangan, hal ini dianggap sama, yang memiliki sifat proporsional terhadap GDP dengan jarak suatu negara yang memiliki hubungan perdagangan (Suryanta 2012).

Berdasarkan kerangka pemikiran dari (Yang S, Zarzosov MI 2013), dan (Beers 2000). Selanjutnya proses analisis dampak IJEPA terhadap arus perdagangan dikawasan ASEAN dan mitra dagang Indonesia ini digambarkan oleh model sebagai berikut:

$$
\begin{aligned}
\operatorname{lnIM}_{\mathrm{ijt}}=\beta_{0}+ & \beta_{1} \operatorname{lnGDP_{it}}+\beta_{2} \ln G D P_{j t}+\beta_{3} \ln D I S T_{i j t} \\
& +\beta_{4} \ln P O P_{i t}+\beta_{5} \ln P O P_{j t}+\beta_{6} D I M_{A N}+\beta_{7} D I M_{M D}+\beta_{8} D F T A t+\varepsilon_{i t}
\end{aligned}
$$

\begin{tabular}{|c|c|}
\hline Variabel & Keterangan \\
\hline $\mathrm{i}$ & ASEAN dan Jepang \\
\hline $\mathrm{j}$ & Amerika, China, Korea Selatan, dan Australia. \\
\hline $\mathrm{t}$ & Waktu \\
\hline $\operatorname{lnIM} \mathrm{M}_{\mathrm{ijt}}$ & $\begin{array}{l}\text { Nilai impor bilateral setiap negara i dan j tahun ke-t (juta USD), } \\
\text { dalam log natural (ln) }\end{array}$ \\
\hline $\ln G D P_{i t}$ & $\begin{array}{l}\text { GDP negara } \mathrm{i} \text { tahun pada tahun } \mathrm{t} \text { (juta USD), dalam logaritma natural } \\
\text { (ln) }\end{array}$ \\
\hline $\ln G D P_{j t}$ & $\begin{array}{l}\text { GDP negara } \mathrm{j} \text { tahun pada tahun } \mathrm{t} \text { (juta USD), dalam logaritma natural } \\
\text { (ln) }\end{array}$ \\
\hline $\ln D I S T_{i j t}$ & $\begin{array}{l}\text { jarak ekonomi negara i ke negara j pada tahun } \mathrm{t} \text {, dalam logaritma } \\
\text { natural (ln) }\end{array}$ \\
\hline $\ln P O P_{i t}$ & Populasi negara i pada tahun $\mathrm{t}$, dalam logaritma natural (ln) \\
\hline $\ln P O P_{j t}$ & Populasi negara j pada tahun $\mathrm{t}$, dalam logaritma natural (ln) \\
\hline$I M_{a n}$ & $\begin{array}{l}\text { Variabel dummy untuk mengindikasikan efek dari trade creation. } \\
\text { Variabel dummy akan bernilai } 1 \text { jika importir negara i adalah negara } \\
\text { anggota ASEAN-Jepang yang melakukan perdagangan dalam } \\
\text { kawasan, dan bernilai } 0 \text { jika eksportir adalah negara j yaitu China, } \\
\text { Korea Selatan, Australia dan Amerika Serikat ke kawasan negara i. }\end{array}$ \\
\hline$I M_{m d}$ & $\begin{array}{l}\text { Variabel dummy untuk mengindikasikan efek trade diversion. } \\
\text { Variabel dummy akan bernilai } 1 \text { jika eksportir adalah negara j yaitu: }\end{array}$ \\
\hline
\end{tabular}

Tabel 1 Keterangan Variabel Model Gravity 


\begin{tabular}{ll}
\hline Variabel & \multicolumn{1}{c}{ Keterangan } \\
& China, Korea Selatan, Australia dan Amerika Serikat ke kawasan \\
& ASEAN Jepang, dan bernilai 0 jika importir negara i. Variabel \\
& dummy yang mengindikasikan efek trade creation dan trade \\
diversion dapat disimpulkan sebagai berikut: \\
- Terjadi efek trade creation jika $\beta 6$ dan $\beta 7$ bertanda positif, \\
• Terjadi efek trade diversion jika $\beta 6$ bertanda positif dan $\beta 7$ bertanda \\
negatif. \\
$\beta_{0}=$ intersep, $\beta_{2}-\beta_{8}=$ slope, $\varepsilon=$ error \\
\hline
\end{tabular}

\section{Generalized Method of Movements (GMM)}

Model GMM untuk melihat konvergensi pertumbuhan ekonomi dari kesepakatan IJEPA dengan negara ASEAN dan Jepang, digambarkan sebagai berikut:

$$
\operatorname{lnGDP} p c_{\mathrm{it}}=\beta_{1} \operatorname{lnGDP} p c_{\mathrm{it}-1}+\beta_{2} \operatorname{lnNX} \mathrm{it}_{\mathrm{it}}+\beta_{3} \ln F D I_{i t}+\beta_{4} \ln H H_{i t}+\beta_{5} D F T A t+\varepsilon_{i t}
$$

Keterangan:

Tabel 2 Keterangan Variabel Model GMM

\begin{tabular}{|c|c|}
\hline Variabel & Keterangan \\
\hline $\mathrm{i}$ & Negara-negara ASEAN, Jepang dan Negara Non anggota \\
\hline $\mathrm{t}$ & Waktu \\
\hline $\ln G D P p c_{i t}$ & $\begin{array}{l}\text { GDP per kapita negara i tahun pada tahun t (juta USD), dalam } \\
\text { logaritma natural (ln) }\end{array}$ \\
\hline $\ln G D P p c_{t-1}$ & $\begin{array}{l}\text { GDP per kapita negara i pada pada tahun sebelumnya (juta USD), } \\
\text { dalam logaritma natural (ln) }\end{array}$ \\
\hline $\ln N X_{i t}$ & $\begin{array}{l}\text { Net ekspor negara i dalam kawasan pada tahun t, dalam logaritma } \\
\text { natural (ln) }\end{array}$ \\
\hline $\begin{array}{c}F D I_{i t} \\
\ln H H_{i t}\end{array}$ & $\begin{array}{l}\text { Foreign Direct Investment negara i dalam kawasan pada tahun t. } \\
\text { Pengeluaran Konsumsi Rumah Tangga negara i pada tahun t, dalam } \\
\text { logaritma natural }(\mathrm{ln}) \text {. }\end{array}$ \\
\hline DFTA $_{t}$ & $\begin{array}{l}\text { variabel dummy untuk mengindikasikan tahun pemberlakukan } \\
\text { FTA. Bernilai } 1 \text { jika tahun ke-t adalah tahun setelah 2008, dan } \\
\text { bernilai } 0 \text { jika tahun ke-t adalah tahun sebelum } 2008 \text {. } \\
\beta_{1}=1+\beta, \beta_{2}-\beta_{7}=\text { slope, } \varepsilon=\text { error }\end{array}$ \\
\hline
\end{tabular}

Pada model konvergensi di atas, menurut (Mutaqin dan Achihashi 2012) jika nilai $\beta$ berada diantara 0 dan -1 maka dapat dikatakan telah terjadi konvergensi pada pertumbuhan ekonomi dikawasan ASEAN-Jepang, dan mitra dagang Indonesia. Jika $\beta$ semakin mendekati -1 maka pertumbuhan ekonomi dikawasan ASEAN-Jepang, dan mitra dagang Indonesia semakin konvergen. Sedangkan jika $\beta<0$ dan $\beta<-1$ maka pertumbuhannya menuju arah yang divergen atau menyebar. Menurut (Jan dan Chaundhary 2011), waktu yang diperlukan untuk menutup setengah dari kesenjangan awal (half life convergence) dihitung dengan perhitungan, sebagai berikut:

$$
H=\frac{\ln 2}{\text { tingkat konvergensi }}
$$




\section{HASIL DAN PEMBAHASAN}

\section{Pengujian Parameter Model}

Dalam penelitian ini, untuk memperoleh model yang cocok dan memperoleh estimasi yang bersifat BLUE maka dilakukan juga pengujian asumsi dasar. Hasil uji chow dan uji hausman test yang bisa dilihat pada Tabel 3, sebagai berikut:

Tabel 3 Hasil Uji Chow dan Uji Hausman

\begin{tabular}{lll}
\hline Uji Model Terbaik & Nilai Probabilitas & Hasil Hipotesis \\
\hline Uji Chow & 0.0000 & Tolak $H_{0}$, maka FEM \\
Uji Hausman & 0.0000 & Terima $H_{0}$, maka REM \\
\hline
\end{tabular}

Hasil uji Chow menunjukan bahwa nilai probabilitas 0,0000 yang mana hasil ini kurang dari taraf nyata yang digunakan sebesar 1 persen. Karena nilai probabilitas pada uji Chow menunjukan lebih kecil dari 1 persen maka cukup bukti untuk melakukan penolakan $\mathrm{H}_{0}$. Sehingga berdasarkan uji Chow model FEM lebih baik digunakan dibandingkan model PLS.

Nilai probabilitas yang ditunjukan pada hasil estimasi uji Hausman sebesar 0.0000. Hasil estimasi pada uji Hausman menunjukan nilai probabilitas 0.0000 lebih dari taraf nyata 1 persen, maka cukup bukti untuk tolak $\mathrm{H}_{0}$. Berdasarkal hasil estimasi uji Hausman maka model FEM lebih baik dibandingkan REM. Berdasarkan uji Chow dan uji Hausman model FEM, hal ini sejalan dengan penelitian yang dilakukan oleh (Lehmann dan Zarzoso 2002) menyatakan dalam menganalisis arus perdagangan model FEM lebih baik digunakan dibandingkan dengan model REM. Jadi model FEM digunakan dalam menganalisis dampak trade creation dan trade diversion antara Indonesia dengan negara-negara anggota ASEAN-Jepang dan non anggota.

\section{Uji Kelayakan dan Kecocokan Model (Goodness of fit)}

Uji kelayakan model menunjukkan bahwa nilai probability ( $F$-Statistic) pada model yang digunakan adalah 0.0000 seperti yang terlihat pada Lampiran 1 sehingga dapat disimpulkan bahwa minimal ada satu variabel bebas yang mempengaruhi variabel tidak bebas. Uji kecocokan model (goodness of fit) ditunjukkan pada nilai koefisien determinasi $\left(\mathrm{R}^{2}\right)$. Model menunjukkan nilai $\mathrm{R}^{2}$ sebesar 0.99 yang berarti 99 persen mampu dijelaskan model dan sisanya dijelaskan oleh variabel lainnya.

\section{Uji Normalitas}

Uji normalitas dilakukan untuk melihat apakah error yang terdapat pada model sudah terdistribusi normal. Uji ini dilakukan dengan melihat nilai probabilitas pada uji normalitas lebih besar dari taraf nyata 5 persen. Tabel 4 menunjukan hasil yang diperoleh dalam uji normalitas model FEM ini didapati nilai probabilitas sebesar 0.262953 atau lebih besar dari taraf nyata 5 persen. Bisa dilihat pada Tabel 4 sebagai berikut:

Tabel 4 Uji Normalitas

\begin{tabular}{lll}
\hline Uji Normalitas & Nilai & Keterangan \\
\hline Jarque Bera & 2.671560 & >taraf nyata 1 persen \\
Probability & 0.262953 & >taraf nyata 1 persen \\
\hline
\end{tabular}

Kondisi ini menandakan bahwa cukup bukti untuk menerima $H_{0}$ atau dengan kata lain error yang terdapat pada model telah terdistribusi dengan normal. Berdasarkan uji ekonometrika menunjukan bahwa model FEM yang digunakan 
bersifat BLUE (Best, Linear, Unbiased, and Estimator).

\section{Uji Homoskedastisitas}

Asumsi pertama yang harus dipenuhi dalam persamaan regresi adalah bahwa perkiraan parameter dalam model regresi bersifat BLUE maka varian $\left(\mathrm{u}_{\mathrm{i}}\right)$ harus sama dengan $\sigma^{2}$ (konstan), atau semua residual atau error memiliki varian yang sama. Kondisi itu disebut dengan homoskedastisitas. Apabila varian tidak konstan atau berubah-ubah disebut dengan heteroskedastisitas. Jika sum squared residual pada weigted statistics nilainya kurang dari sum squared residual pada unweigted statistics maka ada kemungkinan terjadi heteroskedastisitas (Juanda 2009). Dari hasil model panel diperoleh sum square resid weighted 176.66 > dari sum square resid unweigted 84.54 maka sudah Homoskedastisitas.

\section{Faktor-faktor yang Memengaruhi} Impor Indonesia dari Negara-negara ASEAN-Jepang dan Mitra Dagang Indonesia

Berdasarkan hasil estimasi yang ditunjukkan oleh Tabel 5 dapat diketahui bahwa model mempunyai enam variabel independen lainnya yang berpengaruh signifikan terhadap arus impor dengan taraf nyata 1 persen, yaitu GDP ASEAN-Jepang dan non anggota, jarak ekonomi, populasi ASEAN-Jepang dan negara non anggota, dan dummy kebijakan.

Tabel 5 Hasil estimasi koefisien

\begin{tabular}{lccc}
\hline \multicolumn{1}{c}{ Variabel } & Koefisien & Prob & Signifikan \\
\hline GDP $_{\mathrm{i}}$ & 3.332021 & 0.0000 & Signifikan (1 \%) \\
$\mathrm{GDP}_{\mathrm{j}}$ & 6.693706 & 0.0000 & Signifikan (1 \%) \\
Dist $_{\mathrm{ij}}$ & -2.011441 & 0.0000 & Signifikan (1 \%) \\
POP $_{\mathrm{i}}$ & 11.43518 & 0.0000 & Signifikan (1 \%) \\
POP $_{\mathrm{j}}$ & 10.43769 & 0.0000 & Signifikan (1 \%) \\
DFTA & 0.090948 & 0.0042 & Signifikan (1 \%) \\
\hline
\end{tabular}

Berdasarkan hasil olah data dari model gravity ditemukan faktor-faktor yang mempengaruhi arus Impor dari negara-negara ASEAN-Jepang dan mitra dagang Indonesia, faktor yang mempengaruhi sebagai berikut:

\section{GDP Indonesia, ASEAN Jepang dan Non anggota}

Hasil estimasi yang diperoleh model pada Tabel 8 menunjukkan bahwa variabel GDP berpengaruh signifikan terhadap variabel dependen dengan taraf nyata 1 persen, besaran nilainya yaitu 2.93. Artinya setiap peningkatan GDP Indonesia sebesar satu persen akan meningkatkan impor sebesar 2.93 persen, ceteris paribus. Hasil temuan ini sesuai degan hipotesis, GDP merupakan faktor penting dalam perekonomian, hal ini terkait dengan meningkatnya GDP maka permintaan produk impor akan meningkat. Selain itu GDP menunjukan ukuran ekonomi suatu negara, olah karena itu jika GDP meningkat maka suatu negara akan mengimpor dalam jumlah yang lebih besar.

Sementara hasil estimasi pada variabel GDP negara mitra dagang menunjukkan pengaruh yang negatif dan signifikan pada taraf nyata 1 persen dengan nilai koefisiennya sebesar 6.69. Hal ini berarti bahwa peningkatan GDP negara non anggota akan meningkatkan penawaran impor sebesar 6.69 persen, ceteris paribus. Hasil ini sesuai dengan hipotesis menurut (Mankiw 2007) GDP sering digunakan sebagai indikator dalam menentukan arah pembangunan kan dan 
tingkat pendapatan suatu negara, selain itu ukuran ekonomi suatu negara dapat dilihat dari kemampuan potensial negara tersebut untuk melakukan perdagangan, yaitu kemapuan untuk menjual atau membeli produk antar negara. Jadi berdasarkan hal tersebut paningkatan GDP non anggota akan meningakatkan penawaran impor ke kawasan ASEAN Jepang. Hal ini disebabkan oleh tingginya pendapatan rill negara anggota dan non anggota maka akan menyebabkan peningkatan penawaran impor di kawasan negara ASEAN Jepang.

\section{Jarak Ekonomi}

Jarak ekonomi merupakan salah satu syarat yang cukup penting pada gravity model yang menyatakan biaya transportasi merupakan hambatan dalam kegiatan perdagangan dan besarnya jarak ekonomi akan mempengaruhi arus perdagangan impor secara negatif yang sesuai dengan hipotesis. Hasil estimasi yang diperoleh pada Tabel 8 menunjukkan bahwa variabel jarak berpengaruh signifikan terhadap impor dengan taraf nyata 1 persen, besaran nilainya yaitu 2.01 , artinya setiap peningkatan jarak ekonomi sebesar satu persen antar kedua negara yang saling berdagang akan menurunkan impor sebesar 2.01 persen, ceteris paribus. Hal ini sejalan dengan penelitian (Caporale et al. 2011) menemukan pengaruh positif terhadap arus perdagangan dari ukuran negara, dan jarak ekonomi. Menurut Beers (2002) dan Paas (2000) hubungan negatif jarak ekonomi dengan arus perdagangan disebabkan oleh tingginya biaya sehingga harga barang barang impor akan mengalami peningkatan.

\section{Populasi Indonesia dan Populasi Negara ASEAN dan Non Anggota}

Variabel populasi negara anggota berpengaruh signifikan pada taraf nyata 1 persen terhadap impor yang bisa dilihat pada Tabel 11, nilai koefisien sebesar
11.43, artinya setiap kenaikan populasi negara ASEAN Jepang sebesar 1 persen akan meningkatkan impor sebesar 11.43 persen, ceteris paribus. Hal ini sejalan dengan hipotesis peneliti, dimana variabel impor memiliki hubungan positif dengan variabel tingkat populasi, peningkatan ini disebabkan oleh saling terbukanya perdagangan antar negara di kawasan tersebut, dan Indonesia merupakan negara yang memiliki tingkat populasi tinggi, urutan ke 4 di dunia, maka Indonesia menjadi salah satu pasar yang potensial bagi negara anggota dan non anggota.

Variabel populasi negara non anggota berpengaruh positif dan signifikan terhadap variabel impor yang bisa dilihat pada Tabel 8. Nilai koefisien sebesar 0.70, artinya setiap kenaikan populasi sebesar 1 persen akan meningkatkan impor sebesar 0.70 persen, ceteris paribus. Menurut Yang dan Zarzoso (2013) hubungan tingkat populasi suatu negara yaitu negara yang digunakan dalam penelitian negara ASEAN-Jepang, serta non anggota, memiliki hubungan positif dengan varibel impor, dimana setiap peningkatan populasi negara non anggota maka penawaran tenaga kerja akan meningkat, sehingga tingkat produksipun meningkat, hal ini akan meningkatkan penawaran impor dari negara non anggota ke negara ASEAN Jepang.

\section{Dummy FTA}

Variabel dummy FTA pada penelitian ini digunakan untuk menangkap perbedaan tahun saat sebelum dan sesudah IJEPA diberlakukan untuk tiap tahunnya. Hasil estimasi pada Tabel 8 menunjukkan bahwa dummy FTA signifikan pada taraf nyata 1 persen dan koefisiennya positif terhadap arus perdagangan dengan besaran nilai sebesar 0.09. Hal tersebut berarti dummy FTA mampu memperlihatkan perbedaan nilai rata-rata impor sebesar 0.20 lebih tinggi pada saat terjadi FTA 
diberlakukan dibandingkan sebelum terjadinya kesepakatan perdagangan FTA.

\section{Trade Creation dan Trade Diversion antara Negara-negara ASEAN-Jepang dengan Negara Non Anggota}

Trade creation terjadi ketika beberapa produk yang produksi di Indonesia dengan biaya lebih tinggi digantikan dengan produk dari negara anggota pabean atau serikat dengan biaya produksi yang lebih rendah, hal ini menyababkan harga produk impor di Indonesia menjadi lebih murah sehingga akan meningkatkan kesejahteraan (Salvatore 1996). Trade diversion, terjadi ketika impor dengan harga yang lebih rendah dari luar serikat yang digantikan oleh produk dengan harga produk yang tinggi dari anggota pabean atau serikat, dengan sendirinya harga yang di terima Indonesia dari negara anggota akan lebih tinggi sehingga akan mengurangi kesejahteraan (Salvatore 1996). Variabel dummy trade creation dan dummy trade diversion digunakan sebagai variabel yang dapat menangkap dampak dari AJCEP pada arus impor.

AJCEP menyepakati pemberian keistimewaan terhadap tariff. Dari pihak Indonesia, keistimewaan yang diberikan kepada Jepang adalah dengan memberikan perlakuan khusus tariff di 93 persen dari jumlah pos tariff tahun 2006 yang sebanyak 11163 pos tariff. Impor Indonesia dari Jepang dalam pos tariff khusus tersebut telah mencakup 93 persen dari nilai Impor Indonesia dari Jepang. Untuk produk klasifikasi fast-track, sekitar 31 persen dari pos tariff akan diturunkan hingga 0 persen pada saat berlakunya IJEPA. Untuk produk klasifikasi normal track, sekitar 58 persen dari pos tariff secara bertahap akan diturunkan menjadi 0 persen dalam masa tiga hingga 15 tahun sejak berlakunya IJEPA. Sisanya yang 7 persen merupakan produk yang dikecualikan dari pos tariff IJEPA
(Kemenkeu 2011). Tingginya jumlah pos yang dibuka membuat Indonesia harus siap menghadapi babak baru dalam menghadapi perdagangan dengan Jepang, insentif pemerintah sangat diperlukan untuk memicu industri dalam negeri.

Jepang memberikan kepada Indonesia perlakuan khusus tariff di lebih dari 90 persen dari pos tariff Jepang yang berjumlah 9275 pada tahun 2006. Ekspor Indonesia ke Jepang pada pos tariff tersebut mencakup 99 persen dari nilai ekspor Indonesia ke Jepang. Untuk produk klasifikasi fast-track, sekitar 80 persen dari total pos tariff akan diturunkan ke 0 persen pada saat berlakunya IJEPA. Sementara itu, untuk produk-produk dalam klasifikasi normal track sekitar 10 persen dari total pos tariff akan diturunkan hingga 0 persen secara bertahap dalam waktu tiga hingga sepuluh tahun sejak berlakunya IJEPA. Sedangkan 10 persen sisanya akan dikecualikan dari skema tariff IJEPA (Kemenkeu 2011). Berdasarakan hasil olahan data, bisa dilihat pada Tabel 6 merupakan hasil estimasi trade creation dan trade diversion sebagai berikut.

Tabel 6 Hasil estimasi trade creation dan trade diversion

\begin{tabular}{lccc}
\hline Variabel & Koefisien & Prob & Signifikan \\
\hline $\mathrm{DIM}_{\mathrm{an}}$ & 0.92 & 0.0000 & $\begin{array}{c}\text { Signifikan } \\
(1 \%) \\
\text { Signifikan } \\
(1 \%)\end{array}$ \\
$\mathrm{DIM}_{\mathrm{md}}$ & 31.46 & 0.0000 & $\begin{array}{l}\text { S } \\
\text { Sumber: Lampiran (diolah) }\end{array}$
\end{tabular}

Berdasarkan hasil estimasi pada Tabel 9, dummy trade creation dan dummy trade diversion memberikan pengaruh yang signifikan terhadap arus impor Indonesia saat diberlakukannya FTA dengan taraf nyata 5 persen. Nilai koefisien yang bisa dilihat dari Tabel 9 variabel dummy trade creation koefisiennya bernilai 0.92 artinya besarnya koefisien sebesar 0.92 menyatakan rata-rata perbedaan impor dari negara anggota dengan negara non anggota, 
dengan demikian intersep dari variabel dummy impor negara anggota meningkat sebesar 0.92 satuan. Tanda positif pada variabel DIM $_{a n}$ menandakan terjadinya trade cration dari hasil kesepakatan AJCEP. Hal ini sesuai dengan kondisi setelah diadakannya kesepakatan antara Indonesia dengan Jepang pada tahun 2008 nilai impor Indonesia dari Jepang mengalami peningkatan yang signifikan sebesar 15129173 USD, sedangkan pada tahun 2007 sebelum terjadinya kesepakatan impor Indonesia dari Jepang sebesar 6526674 USD pada tahun 2007, peningkatan yang signifikan ini disebabkan oleh kesepakatan perdagangan yang mengurangi hambatan perdagangan, hal ini juga terjadi pada negara-negara ASEAN lainnya seperti: Malaysia, Singapura, Thailand, Filipina, Laos, Vietnam, dan Brunai.

Impor Indonesia dari Jepang pada tahun 2013 diantaranya alat elektronik sebesar 1843200 USD, mesin sebesar 5 736.21 juta USD, dan kendaraan selain kereta api sebesar 2199200 USD, ke tiga produk ini merupakan produk impor tiga besar impor Jepang ke Indonesia. Sementara ekspor Indonesia ke Jepang produk yang diekspor pada tahun 2013 adalah bijih, terak dan abu sebesar 1 017.39 juta USD, karet sebesar 1336880 USD, dan listrik, peralatan elektronik sebesar 1310270 USD. Berdasarkan produk yang diperdagangankan antara Jepang dan Indonesia, produk Indonesia pada umumnya merupakan produk row material yang memiliki nilai atau gap yang jauh dengan produk yang diperdagangkan oleh Jepang ke Indonesia.

Koefisien dummy trade diversion bernilai 31.41 yang bisa dilihat dari Tabel 9, artinya koefisien sebesar 31.41 menyatakan rata-rata perbedaan impor Indonesia dari negara non anggota yang merupakan non anggota dengan negara anggota, dengan demikian intersep dari variabel dummy impor Indonesia dengan mitra dagang menigkat sebesar 31.41 satuan. Tanda positif mengindikasikan adanya trade creation pada arus impor Indonesia dari negara non anggota. Hal ini bisa terjadi disebabkan oleh integrasi ekonomi bilateral terciptanya trade creation sebelum terjadinya kesepakatan dengan membentuk semacam FTA, dengan catatan harus sudah menjadi produsen yang menghasilkan produk dengan harga yang rendah. Terlihat jelas bahwa kerja sama dengan membentuk blok perdagangan akan menciptkan trade creation, semakin luas maka trade creation yang diciptakan akan semakin besar (Clausing 2001). Selain itu hasil dari kesepakatan ini menghasilkan efek trade creation yang artinya dengan adanya perbedaan tariff untuk beberapa produk yang disepakati melalui AJCEP, menyebabkan permintaan produk impor Indonesia yang ditawarkan oleh negara non anggota tidak mengalami penurunan. Sehingga aliran perdagangan dari negara non anggota tidak terhambat dari kesepakatan ini

Jadi dalam kesepakatan ASEAN-Japan Comprehensive Economic Partnership (AJCEP) dan negara non anggota menghasilkan koefisen variebel $\beta_{6}$ dan $\beta_{7}$ positif, sehingga bisa dikatakan terjadinya trade creation hal ini sesuai dengan teori integrasi ekonomi (Clausing 2001). Pada beberapa produk yang disepakati dalam AJCEP yang juga ada beberapa produk impor yang sama dari negara non anggota. Permintaan Indonesia dari negara anggota tidak dihalangi oleh kesepakatan ini terbukti pada koefisien $\beta_{7}$ yang positif yang menyatakan tingginya permintaan produk impor dari negara non anggota walaupun ada kesepakatan ini. Selain itu Indonesia juga lebih bebas memilih atau membeli produk impor untuk jenis produk yang sama dari negara anggota atau non anggota yang harga murah dan dari kebijakan AJCEP tidak mempengaruhi permintaan impor 
Indonesia dari negara non anggota. Pilihan produk impor menjadi lebih banyak yang nantinya akan mendorong kesejahteraan masyarakat. Trade creation yang terjadi pada kesepakatan AJCEP akan meningkatkan kesejahteraan negara-negara bukan anggota karena kenaikan pendapatan rill di antara negara-negara anggota tersebut, nantinya permintaan barang impor akan meningkat (Salvatore1996).

Tabel 7 Kriteria Uji Model GMM

\begin{tabular}{lccc}
\multicolumn{1}{c}{ Variabel } & PLS & FE & SYS-GMM \\
\hline GDPpc t-1 & 0.9846774 & 0.8023061 & 0.9846583 \\
Prob & {$[0.000]^{*}$} & {$[0.000]^{*}$} & {$[0.000]^{*}$} \\
\hline AB Test & $\mathrm{z}$ & \multicolumn{3}{c}{ Prob $>\mathrm{z}$} \\
Arellano-Bond $m 1$ & -2.1729 & \multicolumn{2}{c}{$0.0298^{* * *}$} \\
Arellano-Bond $m 2$ & 1.2982 & \multicolumn{2}{c}{0.1942} \\
\hline Sargan Test
\end{tabular}

Sargan Test

chi $^{2} \quad 10.23058$

Prob>chi square

1.0000

Hasil estimasi pada Tabel 7 uji tak bias, jika estimator berada diantara estimator PLS dan FE. Koefisien lag variabel dependen yang dihasilkan oleh SYS-GMM sebesar (0.9846583) berada diantara estimator PLS (0.9846774) dan FE (0.8023061) hal ini menunjukan model SYS-GMM tidak bias. Untuk uji validitas menggunakan uji sargan, dari hasil olahan menunjukan nilai chi square (10.23058) dengan probabilitas (1.0000) yang tidak signifikan karena menunjukan tidak tolak H0. Hal ini menunjukan bahwa hasil estimasi valid karena tidak ada korelasi antar residual dan over indentifiying restriction.

Uji konsisten pada Tabel 8 menggunakan uji Arrelano-Bond (AB) menyatakan bahwa uji statistik $m 1$ (0.0298) signifikan pada taraf nyata 5 persen atau menunjukkan cukup bukti untuk menolak H0. Sedangkan statistik $m 2$ (0.1942) tidak signifikan pada taraf nyata 5 persen atau menunjukan nilai tidak cukup bukti untuk tolak H0. Sehingga tidak ada

\section{Model Konvergensi Pertumbuhan Ekonomi}

Kriteria pemilihan model GMM adalah dengan menggunakan untuk uji model terbaik yang bisa dilihat pada Tabel 12 dengan menggunakan uji tak bias, uji validitas dan uji konsistensi (Firdaus 2011). Bisa dilihat pada Tabel 7 kriteria uji model GMM sebagai berikut: masalah autokorelasi sehingga model menjadi konsisten.

\section{Konvergensi Pertumbuhan Ekonomi dari Kesepakatan Indonesian-Japan Economic Partnership Agreement (IJEPA) antara Indonesia dengan negara ASEAN-Jepang dan Mitra Dagang Indonesia}

Hasil estimasi konvergensi pertumbuhan ekonomi pada Tabel 8 merupakan model dinamis. Pemasukan lag variabel dependen pada panel statis akan menghasilkan estimasi yang bias dan tidak konsisten hal ini disebabkan oleh masalah endoginty pada lag variabel dependen. Dari hasil olahan GMM bisa dilihat pada Tabel 8 Hasil estimasi konvergensi kondisional GDPpc dengan model SYS-GMM, sebagai berikut:

Tabel 8 Hasil Estimasi Konvergensi GDP per kapita dengan model SYS-GMM

\begin{tabular}{cc}
\hline Variabel & SYS-GMM \\
\hline GDPpc t-1 & 0.9846583 \\
Prob & {$[0.000]^{*}$} \\
\hline
\end{tabular}


Tabel 8 koefisien GDPpc $\mathrm{t}_{\mathrm{t}-1}$ dengan model SYS-GMM menunjukan nilai sebesar (0.9846583), yaitu nilai prob 0.000 kurang dari taraf nyata 5 persen, artinya tolak H0 sehingga variabel $\mathrm{GDPpc}_{\mathrm{t}-1}$ signifikan pada traf nyata 5 persen. Koefisien menunjukan nilai yang berada diantara 0 dan -1 dikatakan terjadi konvergensi, yang mana nilai koefisien

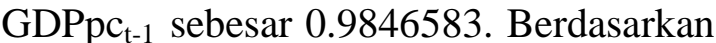
nilai ini diketahui bahwa nilai $\beta$ sebesar -0.0153417 yang kurang dari -1 , sehingga dapat dikatakan bahwa secara statistik terjadi konvergensi di kawasan ASEAN Jepang dan mitra dagang Indonesia.

Tingkat konvergensi diperoleh dari pengurangan koefisien lag dikurangi satu didapatkan nilai sebesar -0.0153417, sehingga masing-masing negara untuk mencapai tingkat konvergensi $(-\ln (\beta))$, maka tingkat pertumbuhan sebesar 2.0 persen per tahun dengan asumsi cateris paribus, yang menyatakan proses konvergensi berjalan cukup lama. Waktu yang dibutuhkan untuk mencapai kondisi konvergen di negara ASEAN atau half life of convergence $(\mathrm{H}=\ln 2$ : Tingkat konvergensi) sekitar 34 tahun. Variabel yang memengaruhi pendapatan, yaitu total perdagangan, consumption final expenditure, FDI dan dummy FTA yaitu kebijakan pemerintah dengan melakukan kesepaktan liberalisasi perdagangan.
Secara statistik telah diketahui bahwa perekonomian di negara ASEANJepang dan mitra dagang Indonesia memiliki kecenderungan akan tumbuh menuju satu titik yang sama (konvergen). Hal ini dibuktikan dengan kondisi riil pada GDP per kapita di negara ASEAN-Jepang dan mitra dagang Indonesia yang bisa dilihat pada Gambar 3 dan 4, dimana kondisi riil ini menunjukkan bahwa pertumbuhan ekonomi negara-negara ini tumbuh secara konvergen meskipun terdapat gap yang cukup besar antara pendapatan negara maju dan berkembang. Selisih dari pendapatan atau gap dari negara maju dan berkembang ini dipercaya akan semakin mengecil dikarenakan pertumbuhan ekonomi di negara berpendapatan tinggi semakin lambat seiring peningkatan pendapatan.

Di sisi lain, negara dengan pendapatan rendah memiliki pertumbuhan yang tinggi, sehingga pada akhirnya negara berpendapatan rendah ini mampu mengejar ketertinggalannya. Hasil temuan untuk mengejar ketertinggalan negara berkembang dari negara maju di perlukan waktu yang cukup lama, yakni sekitar 34 tahun untuk mengejar setengah dari ketertinggalan. Hal ini menjadi masalah utama untuk negara berkembang karena harus mendorong perekonomian agar bisa tumbuh lebih cepat.

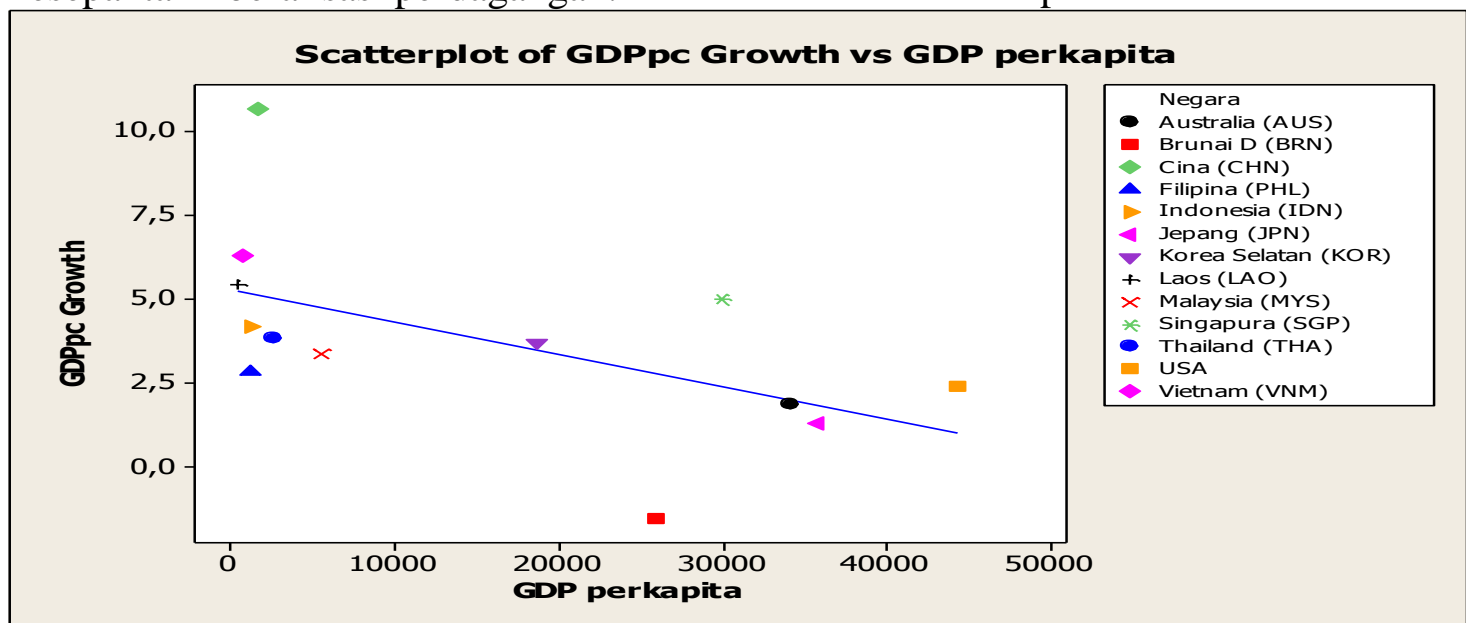

Sumber: WDI. (diolah)

Gambar 3 Plot pertumbuhan Ekonomi dan GDP per kapita di negara ASEAN-Jepang dan Mitra Dagang Indonesia tahun 2005 


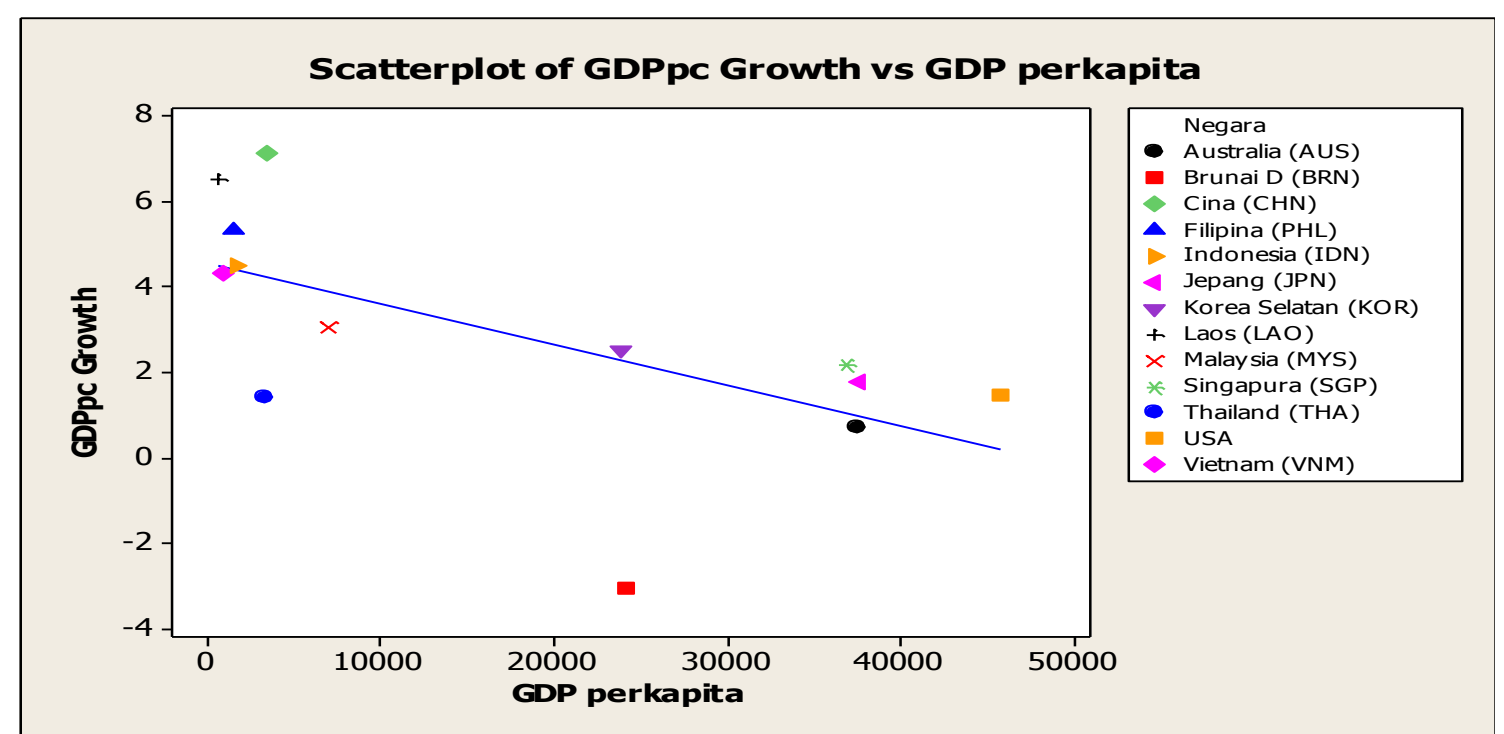

Sumber: WDI. (diolah)

Gambar 4 Plot pertumbuhan Ekonomi dan GDP per kapita di negara ASEAN- Jepang dan Mitra Dagang Indonesia tahun 2013

Gambar 3 dan 4 menujukkan plot pertumbuhan ekonomi dan GDP per kapita di masing-masing negara. Gambar 3 menunjukkan plot pada tahun awal periode penelitian yaitu tahun 2005. Sedangkan Gambar 3 menunjukkan plot pada tahun akhir periode penelitian. Secara umum kedua gambar tersebut menunjukkan slope yang negatif antara pertumbuhan ekonomi dan GDP per kapita di masing-masing negara.

Pada Gambar 3 terlihat bahwa China adalah negara dengan tingkat pertumbuhan tertinggi namun dengan tingkat pendapatan yang relatif rendah, hal ini sama dengan negara Indonesia, Laos, Vietnam memiliki pertumbuhan tinggi dan GDP per kapitanya rendah. Disisi lain, Jepang, Australia, Brunai Darussalam dan Singapura merupakan emapt negara dengan tingkat pendapatan tertinggi namun memiliki tingkat pertumbuhan yang relatif rendah. Pada gambar juga terlihat bahwa rata-rata negara berpendapatan rendah memiliki tingkat pertumbuhan yang lebih tinggi. Hal inilah yang diharapkan dapat menjadi sarana bagi negara berpendapatan rendah untuk mengejar ke tingkat pertumbuhan yang lebih tinggi.

Pada Gambar 4 terlihat pergeseran plot dari masing-masing negara yang menuju titik di kanan bawah grafik. Hal ini semakin mendukung bahwa GDP per kapita masing-masing negara terus meningkat namun dengan tingkat pertumbuhan yang semakin melambat. Penurunan pertumbuhan ini dikarenakan bahwa semakin meningkatnya pendapatan suatu negara maka negara tersebut akan semakin mendekati kondisi steady state.

\section{PENUTUP}

\section{Kesimpulan}

Berdasarkan hasil penelitian, arus perdagangan impor Indonesia dan negara ASEAN Jepang serta negara non anggota mengalami peningkatan ketika perjanjian perdagangan barang dalam AJCEP diberlakukan sebagai dampak dari integrasi regional. GDP negara-negara ASEAN Jepang dan non anggota, jarak ekonomi, populasi Indonesia, populasi negara-negara ASEAN-Jepang dan mitra dagang, dan, dummy trade creation, dummy trade diversion dan dummy 
kebijakan FTA faktor yang dapat mempengaruhi perdagangan impor ASEAN-Jepang saat AJCEP telah diberlakukan.

Hasil estimasi pada penelitian ini menunjukkan bahwa sektor perdagangan negara ASEAN Jepang mengalami trade creation. Hal ini dapat dilihat dari arus perdagangan antara negara ASEAN Jepang dengan negara non-anggota sebesar 31.41 satuan lebih besar dari tingkat perdagangan yang saat ini dilakukan dengan negara non-anggota. Secara keseluruhan, Indonesia dan negara ASEAN Jepang mengalami keuntungan akibat terjadinya trade creation yang berdampak pada peningkatan pendapatan pemerintah dari tarif yang di terima pemerintah dari negara non anggota dan kesejahteraan nasional yang didapat dari harga produk impor yang rendah yang berasal dari negara-negara diluar kawasan ASEAN-Jepang.

Hasil estimasi pada penelitian ini menunjukan terjadinya konvergensi pertumbuhan per kapita masing-masing negara anggota dan negara non anggota, dengan tingkat pertumbuhan untuk mencapai kondisi steady state sebesar 2.0 persen per tahun dengan asumsi cateris paribus. Waktu yang dibutuhkan untuk mencapai kondisi konvergen di negara ASEAN atau half life of convergence sekitar 34 tahun.

\section{Saran}

Berdasarkan hasil penelitian yang diperoleh, ada beberapa hal yang dapat disarankan, sebagai berikut:

1. Dari hasil pembahasan ditemukan terjadinya trade creation dari AJCEP hal ini menjadi keuntungan tersendiri bagi negara ASEAN Jepang, khususnya Indonesia, oleh karena itu pemerintah Indonesia seharusnya mampu memanfaatkan kesempatan ini untuk peningkatan impor Indonesia dengan cara pemerintah harus meningkatkan pendapatan rill, menjaga stabilitas pertumbuhan penduduk, menjaga hubungan dagang Indonesia dengan negara non anggota agar dapat memperoleh produk impor dengan harga yang rendah, dan memanfaatkan liberalsisasi perdagangan demi meningkatkan kesejahteraan masyarakat Indonesia.

2. Berdasarkan hasil dari penelitian diketahui bahwa konvergensi pendapatan per kapita masih memiliki laju yang lambat di ASEAN Jepang dan negara non anggota. Sehingga disarankan kepada pemerintah Indonesia harus dapat meningkatkan investasi pada sektor rill yang produktif, nantinya dapat mendorong produktifitas sehingga akan mampu meningkatkan output nasional, selain itu pemerintah Indonesia harus menjaga hubungan baik dengan negara anggota dan negara non anggota yang dapat mendorong arus perdagangan, sehingga akan meningkatkan pertumbuhan ekonomi Indonesia melalui hubungan perdagangan antar negara yang nantinya akan meningkatkan output nasional.

3. Dari model yang digunakan dalam penelitian ini, dapat dikembangkan model lebih lanjut guna memperoleh hasil yang lebih baik, oleh karena itu saran peneliti leih lanjyt adalah, penambahan jenis variabel dari proksi trade creation atau trade diversion. Hal ini dimaksudkan agar terlihat pengaruh trade creation atau trade diversion bukan hanya arus impor tetapi arus ekspor, dan melakukan spesifikasi produk untuk melihat pengaruhnya dari sisi komoditi. Penambahan cakupan penelitian 
dengan memasukkan kawasan lain sebagai pembanding dimana Indonesia menjadi negara anggota. Menggunakan metode lain, seperti Global Trade Analysis Project (GTAP) atau Computable General Equilibrium (CGE), dalam melihat dampak perekonomian secara menyeluruh.

\section{DAFTAR PUSTAKA}

[ADB] ASEAN Development Bank. 2013. Asian Development Outlook 2013. [Internet]. [diunduh 2015 Maret 12]. Tersedia pada: http://www.adb.org/main.

ASEAN. ASEAN free trade area (AFTA Council). [Internet]. [diunduh 2015 Maret 12]. Tersedia pada: http://www.asean.org/ 19585.htm.

[BPS] Badan Pusat Statistik. 2010. Ekspor dan impor. [Internet]. [diunduh 2015 Maret 12]. Tersedia pada: www.bps.go.id.

Beers VC. 2000. Is the gravity model a flawed instrument in measuring cconomic integration effects. Department of Economics Journal. 38 (2): 1-10.

Caporale MG, Rault C, Sova R, Sova A. 2011. Europe agreements and trade balance: Evidence from four new EU members. IZA Discussion Paper. 5683: 1-35.

Clausing KA. 2001. Trade creation and trade diversion in the Canada-United States free trade agreement. The Canadian Journal of Economics. 34(3): 676-696.

[CPII] Center d' Etudes Prospective et d'Informations International. Geodesic Distance. [Internet]. [diunduh pada 2015 Maret 12]. Tersedia pada: http://www.cpii.fr//dist_cpii.zip.
Firdaus M. 2011. Aplikasi Ekometrika untuk Data Panel dan Time Series. Bogor (ID): IPB Press.

Gujarati D. 2006. Dasar-Dasar Ekometrika Jilid 2. Jakarta (ID): Erlangga.

[IFS] International Financial Statistics. 2013. Software IFS December 2010.

Jan, Chaudhary. 2011. Testing the conditional convergence hypothesis for Pakistan. Business Administration and Economics Journal. 5(1): 117-128.

Juanda B. 2009. Ekometrika : Pemodelan dan Pendugaan. Bogor (ID). IPB Press.

Kementrian Keuangan. 2011. Free trade agreement (FTA) dan economic partnership agreement (EPA), dan pengaruhnya terhadap arus perdagangan dan investasi dengan negara mitra. [Internet]. [diunduh pada 2015 Februari 18]. Tersedia pada:

http://www.kemenkeu.go.id/laporan -hasil-kajian-pusatkebijakan-regiona 1-bilatera.

Kementrian Perdagangan Republik Indonesia. 2011. Kajian dampak perdagangan bebas terhadap daya saing produk manufaktur indonesia. [Internet]. [diunduh pada 2015 Februari 18]. Tersedia pada: http://www.kemendag.go.id.

Kementrian Perdagangan . 2014. Masyarakat ekonomi ASEAN 2015. [Internet]. [diunduh pada 2015 Februari 18]. Tersedia pada: http://www.kemendag.go.id /kerjasama-perdagangan-internasion al.

Lehmann NF, Zarzoso MI. 2002. Augmented gravity model: An empirical application to mercosur european union flows. Journal of Applied Economics. 6(2): 291-316.

Mankiw NG. 2007. Makroekonomi 6th ed. Jakarta (ID): Erlangga. 
Mutaqin Z, Achihashi M. 2012. The Role of maastricht criteria and membership in determining convergence in the eurozone and ASEAN: A panel data analysis. Journal of Applied Economics. 2(7): $1-21$.

Salvatore D. 1996. Ekonomi Internasional 5th ed. Jakarta: Erlangga.

Suryanta B. 2012. Aplikasi rejim persamaan model gravitasi yang telah dirubah pada kasus dinamika arus perdagangan indonesia dengan mitra dagang dari ASEAN. [Internet]. [diunduh pada 2015 April 12]. Tersedia pada: http://www.bi.go.id./buletin-ekonom i-moneter-perdagangan.

Starck CS. 2012. The theoretical foundation of gravity modeling: What are the developments that have brought gravity modeling into mainstream economics. [tesis].
Denmark: Copenhagen Business School.

Trade Map. 2015. Data ekspor dan impor tahun 2000-2012. [Internet]. [diunduh pada 2015 Februari 5]. Tersedia pada: www.trademap.com

[WB]. World Bank. 2013. World development indicator. [Internet]. [diunduh pada 2015 Februari 20]. Tersedia pada: http://data.worldbank.org/data-catal og/world-development-indicators.

[WTO] World Trade Organization. 2013. Annual report 2013. [Internet]. [diunduh pada 2014 Desember 20]. Tersedia pada: https://www.wto.org/english/res_e/b ooksp_e/anrep_e/anrep13_e.pdf.

Yang S, Zarzosov MI. 2013. Panel data analysis of trade creation and trade diversion effects: The case of ASEAN-China free trade area (ACFTA). Platz der Göttinger Sieben 3. hlm: 1-39. 